\title{
Effect of Calcium Hypochlorite in Drip Irrigation System After Application of Red Potassium Chloride
}

\author{
F. L. Suszek ${ }^{1}$, M. A. Vilas Boas ${ }^{1} \&$ S. C. Sampaio ${ }^{1}$ \\ ${ }^{1}$ School of Agricultural Engineering, Western Paraná State University, Cascavel, Brazil \\ Correspondence: F. L. Suszek, School of Agricultural Engineering, Western Paraná State University, Cascavel, \\ Brazil. E-mail: flsuszek@hotmail.com
}

Received: November 1, 2018

Accepted: December 3, 2018

Online Published: February 15, 2019

doi:10.5539/jas.v11n3p180

URL: https://doi.org/10.5539/jas.v11n3p180

\begin{abstract}
The use of water in agriculture should be monitored in order to be more efficient, with irrigation being the largest consumer of water in rural areas. Small farmers who are part of family farming have few resources to develop profitable activities and aiming their well-being, have created family irrigation kits which is a small drip irrigation system. The systems durability depends of some factors like clogging risk of drippers, which is often caused by the quality of the water used or the application of fertilizers to the irrigation water. This research aimed to analyze a family irrigation system with application of red potassium chloride, followed by a chemical agent to clear drippers (calcium hypochlorite) with water application before and after the fertilizer and chemical products (four treatments). At the after, the evaluations were analyzed with statistical quality control charts where the problem was detected in the final of application of the fertilizer, and the process capacity was analyzed showing that it was capable and also was analyzed the degree of system clogging in relation to the obstruction with the fertilizer and clearing with the chemical agent, which resulted in the recovery of the irrigation system (initial flow and distribution uniformity same the final) with recommendations for the use of fertilizers by drip irrigation like open the end lines after the fertigation and dissolve the fertilizer fully before application.
\end{abstract}

Keywords: emission uniformity, localized irrigation, statistical quality control, clogging rate

\section{Introduction}

In 2010, irrigation activity was responsible for $54 \%$ of the water withdrawal in Brazil, followed by urban, industrial, animal and farm human supplies (ANA, 2012).

Irrigation has contributed greatly to the increase in world agricultural production in recent decades. Approximately $62 \%$ of the world's irrigated area uses surface water sources, while $38 \%$ of the areas are irrigated with groundwater (FAO, 2011). According to Christofidis (2006), irrigated areas account for $18 \%$ of the world's arable land and represent $44 \%$ of agricultural production.

Although Brazil has approximately 29 million hectares of irrigation potential, only 5.8 million hectares are irrigated (ANA, 2015), but the potential for expansion of the irrigation area may be much higher.

According to Tolentino Júnior, Marinho, Souza, and Frizzone (2014), drip irrigation is one of the fastest growing technologies in irrigated agriculture. That irrigation is characterized by the application of small volumes of water with high frequency and directly in the root zone of the crops, keeping the soil close to the field capacity and avoiding water loss through evaporation and deep percolation (Frizzone, Freitas, Rezende, \& Faria, 2012).

Based on the lack of time and resources for small farmers, family farming in the most, "irrigation kits" were set up by some irrigation companies, which are more economical and do not require as much other systems. According to IBGE (2009), family agriculture occupies $24.3 \%$ of the area of agricultural establishments in Brazil, totaling 80.25 million hectares, or $9.4 \%$ of the country's total area.

The quality of water used in irrigation should be considered as factor that can cause damage to the irrigation system. According to Capra and Scicolone (1998), the clogging is based on the quality of the irrigation water and its effect is corresponding in the flow of the emitters causing unevenness in the field. Ribeiro, Paterniani, and Colleti (2008) have used chemical treatments in irrigation (chemigation) water based on nitric acid and sodium hypochlorite to clear clogged emitters by biological material, obtaining improvement in the uniformity. 
For the evaluation of processes in any area, statistical quality control charts are used to observe the quality characteristics of interest, ensuring their maintenance within established limits and indicating when to take corrective and improvement actions. They also allow the systematic reduction of variability in quality characteristics, in an effort to improve the intrinsic quality, productivity and reliability of production or supply (Henning, Walter, Souza, \& Samohyl, 2014).

The quality control charts are useful for the operational simplicity and effectiveness in problem detection (Pedrini \& Ten Caten, 2011), and are used successfully in the monitoring of many processes, including for monitoring irrigation systems (J. Frigo, Vilas Boas, J. P. Frigo, \& E. Frigo, 2016). The application of control charts assumes that the process quality characteristic data is independent and identically distributed. If these assumptions are not satisfied, the performance of the control chart may be insufficient, which generates a high number of false alarms or loss of efficiency in the detection of special causes (Aizenchtadt, Ingman, \& Friedler, 2008).

According to Montgomery (2013), the mean and standard deviation should be estimated from preliminary samples or subgroups when process control is expected. These estimates should be based on at least 20 to 25 samples. After that, the capability process index $(\mathrm{Cp})$ can be analyzed. The $\mathrm{Cp}$ relates the variability allowed with the natural process variability, and thus it is assumed that the higher $\mathrm{Cp}$ value means the process capacity to satisfy the specifications, as long as the average is centered on nominal value (Gonçalves \& Werner, 2009).

Based on was presented, this work had the objective of evaluating the process of unclogging of drippers with calcium hypochlorite in a drip irrigation system after the application of red potassium chloride.

\section{Material and Methods}

The experiment was conducted at a rural property in the city of Salto do Lontra, in the South region of Brazil, with geographical coordinates $25^{\circ} 44^{\prime} 04^{\prime \prime} \mathrm{S}$ and $53^{\circ} 12^{\prime} 49^{\prime \prime} \mathrm{W}$ with an altitude of 484 meters, under cultivation of grapevine. A drip irrigation system, model KIFNET, brand NETAFIMTM, with nominal flow of $2.0 \mathrm{~L} \mathrm{~h}^{-1}$ was installed at the service pressure of $100 \mathrm{kPa}$, with spacing of $0.30 \mathrm{~m}$ between drippers.

The system was guided by gravity, formed by a screen filter, and a chemical applicator was mounted next to the water reservoir to mix the products before the field application.

The family farming irrigation kit consists of a 1" polyethylene tubing, a 1" ball valve, a 1" screen filter, and drip tubes with initial connectors. The water tank is extremely necessary, however it is not included in the kit, therefore, we installed it.

Six assessments, with three replicates (16 samples by replicate), were made for each treatment, resulting in 24 assessments, necessary for the use of statistical quality control charts. Table 1 shows the description of the treatments used.

Table 1. Description of the treatments used to the assessments for the analyze with control charts

\begin{tabular}{lll}
\hline Treatment & Assessments & Replicates \\
\hline T1: Irrigation before chemigation & 6 & 3 \\
T2: Fertigation with $\mathrm{KCl}$ & 6 & 3 \\
T3: Chemigation with $\mathrm{Ca}(\mathrm{ClO})_{2}$ & 6 & 3 \\
T4: Irrigation after chemigation & 6 & 3 \\
\hline
\end{tabular}

The fertigation was made with red potassium chloride $(\mathrm{KCl})$ diluted in water, with $60 \%$ being the concentration of $\mathrm{K}_{2} \mathrm{O}$ in the fertilizer, positioned in a chemical tank above the water tank, with a bottle receiving the fertilizer with a floating ball tap, to keep the pressure and incoming flow of the chemical in the water tank as constant as possible (Figure 2). The amount applied of $\mathrm{KCl}$ was based on the soil analysis done in the area and following the recommendations of EMBRAPA (2011), for grapevine cultivation in red nitosol and this amount was applied in a short period of time (six days), like the local farmers are usual to do for the season.

The cleaning system process was made with calcium hypochlorite $\left(\mathrm{Ca}(\mathrm{ClO})_{2}\right)$ because the use of sodium hypochlorite could damage the crop and the soil. It was applied $150 \mathrm{~g}$ to $1.5 \mathrm{~m}^{3}$ of water, with $65 \%$ active chlorine, according to the product label recommendation. This product is easy to obtain because it is common to use in swimming pools cleaning.

Was used for dilution of the fertilizer and chemical products, 100 liters of water, incorporated to the irrigation water after the dilution. 
The data collection methodology of Keller and Karmeli (1975) was used, in which the first, 1/3, 2/3 and the last lateral lines were selected for sampling, with the flow collection in the first, $1 / 3,2 / 3$ and the last drippers per selected line. Figure 1 shows the assembly scheme of the collection structure.

The evaluations occurred with the use of collectors below the drippers with low pressure variation, in four minutes each collection, resulting sample flows. The pressure was measured by digital manometers and the flow measured by graduated test tubes.

The flows were collected at the same time for each lateral line, using a structure with steel cables. The drip line evaluated had its high level about $20 \mathrm{~cm}$ so that collectors were placed below the drops with one hour of irrigation time per assessment.

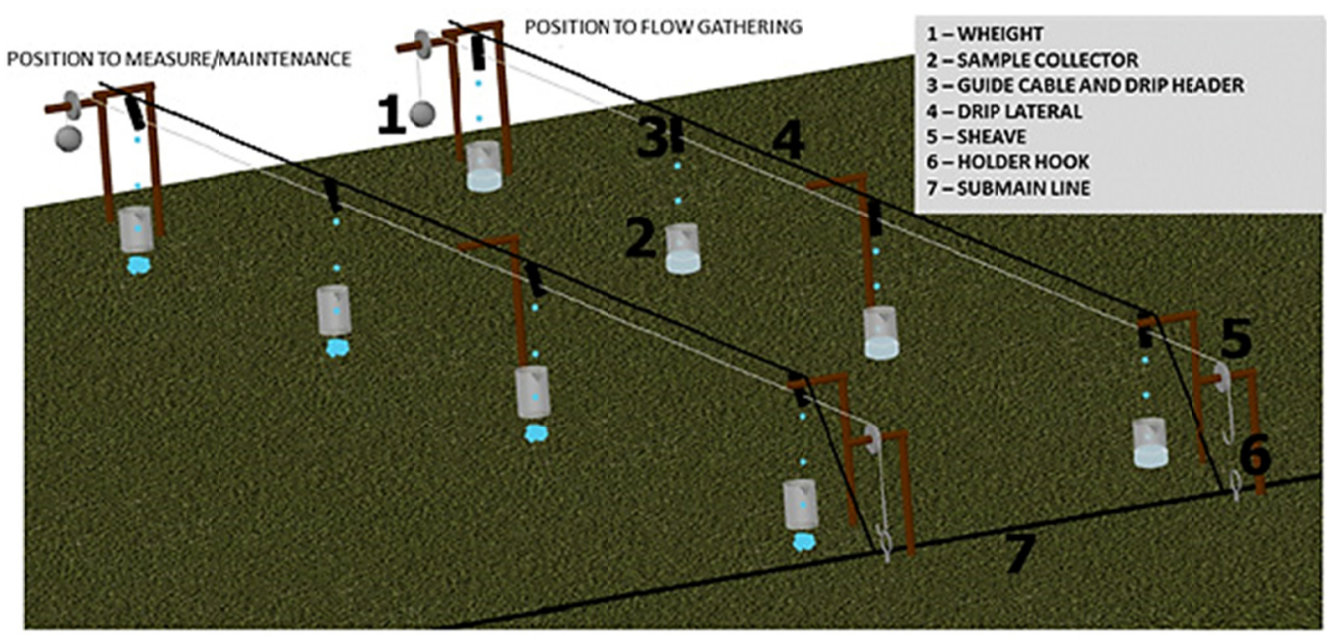

Figure 1. Layout of assembly and operation of the flow collection structure

The sketch of the experimental area can be visualized in Figure 2.

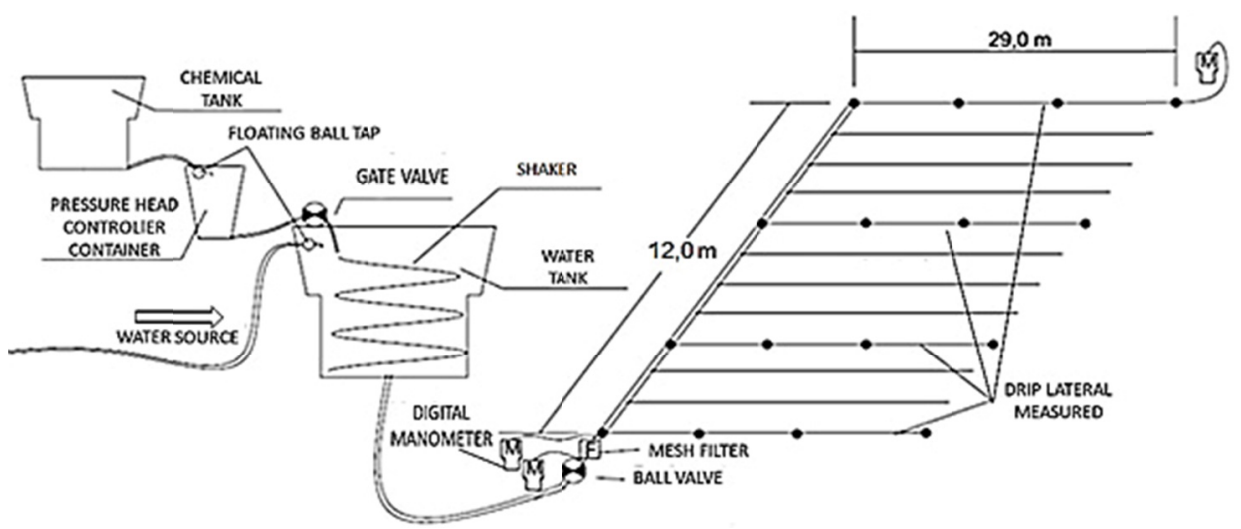

Figure 2. Sketch of the experimental area

The DU (Distribution Uniformity) and the cv (Coefficient of Variation of Flow in the Field) were calculated from Equations 1 and 2, respectively.

$$
\mathrm{DU}=\frac{\mathrm{q}_{25 \% \min }}{\overline{\mathrm{q}}} \times 100
$$

Where, the DU is in \%; $\mathrm{q}_{25 \% \text { min }}$ is the average of the observed flows lowest quartile, $\mathrm{L} \mathrm{h}^{-1} ; \overline{\mathrm{q}}$ is the average flow of the all evaluated drippers, $\mathrm{L} \mathrm{h}^{-1}$.

$$
\mathrm{cV}=\frac{\mathrm{Sd}}{\overline{\mathrm{q}}}
$$


Where, the $\mathrm{cv}$ is in \%; $\mathrm{Sd}$ is the standard deviation of the observed flows, $\mathrm{L} \mathrm{h}^{-1}$.

With the uniformities determined was possible to analyze the clogging over time by the variation of this uniformity with irrigation and fertigation, due to the flow variations in the system.

The flow rates of the drippers in each treatment, allowed the calculation of the clogging rate (CR), where the influence of the discharge clogging of the emitters could have been verified. The calculation of the CR follows from Equation 3.

$$
\mathrm{CR}=\left(1-\frac{\mathrm{q}_{2}}{\mathrm{q}_{1}}\right) \times 100
$$

Where, $\mathrm{CR}$ is in $\%$; $\mathrm{q}_{2}$ is the flow after the fertigation, $\mathrm{Lh}^{-1}$; and $\mathrm{q}_{1}$ is the flow before fertigation, $\mathrm{L} \mathrm{h}^{-1}$.

Statistical quality control charts of individual measures were used to monitor the data, showing points where the process goes out of control, corresponding to specific or special causes problems, from a mean, and control limits given by 3 standard deviations $(\sigma)$ from the mean according to ISO 7870 (2013).

The specification limits used were based on the classification of the coefficients of uniformity DU and $\mathrm{cv}$, according to $\operatorname{ASABE}(1996,2008)$, maintaining the system with a minimum good distribution $(>75 \%)$ and flow variation above the unacceptable value $(>0.15)$.

Maintaining the uniformity within the statistical quality control range with a flow rate close to nominal, the drip system is maintained in good working order for a longer period, with high uniformity and becoming economically viable for small farmers.

The Cp can be calculated by Equation 4, and the process can be considered capable if CP is greater than 1.0.

$$
\mathrm{C}_{\mathrm{P}}=\frac{\text { USL }- \text { LSL }}{6 \sigma}
$$

Where, the USL is the upper specification limit; LSL is the lower specification limit; $\sigma$ is the standard deviation of the process considering absence of special causes.

\section{Results}

The irrigation water quality is shown in Table 2, with the classification to the emitters clogging risk according Capra and Scicolone (1998), and Nakayama and Bucks (1991).

Table 2. Classification of irrigation water used to the emitters clogging risk

\begin{tabular}{llll}
\hline \multirow{2}{*}{ Clogging factor } & & \multicolumn{2}{c}{ Risk factor } \\
\cline { 3 - 4 } & & $\mathrm{a}$ & $\mathrm{b}$ \\
\hline Suspense solids $\left(\mathrm{mg} \mathrm{L}^{-1}\right)$ & 12.00 & low & low \\
Electrical conductivity $\left(\mathrm{dS} \mathrm{m}^{-1}\right)$ & 0.12 & low & low \\
$\mathrm{pH}$ & 6.75 & n.c. & low \\
Iron $\left(\mathrm{mg} \mathrm{L}^{-1}\right)$ & 124.00 & high & high \\
Manganese $\left(\mathrm{mg} \mathrm{L}^{-1}\right)$ & 12.00 & high & high \\
Calcium $\left(\mathrm{mg} \mathrm{L}^{-1}\right)$ & 68.00 & low & n.c. \\
Magnesium $\left(\mathrm{mg} \mathrm{L}^{-1}\right)$ & 133.00 & high & n.c. \\
\hline
\end{tabular}

Note. (a) Classification according Capra and Scicolone (1998); (b) Classification according Nakayama \& Bucks (1991); n.c.: not classified.

The results of the statistical control and process capacity analyzes for DU and the cv are presented in Figure 3, together with the average flow data of the emitters (q), pressure from start irrigation system (Ps) and pressure from end irrigation system $(\mathrm{Pe})$ pressures of the system. 

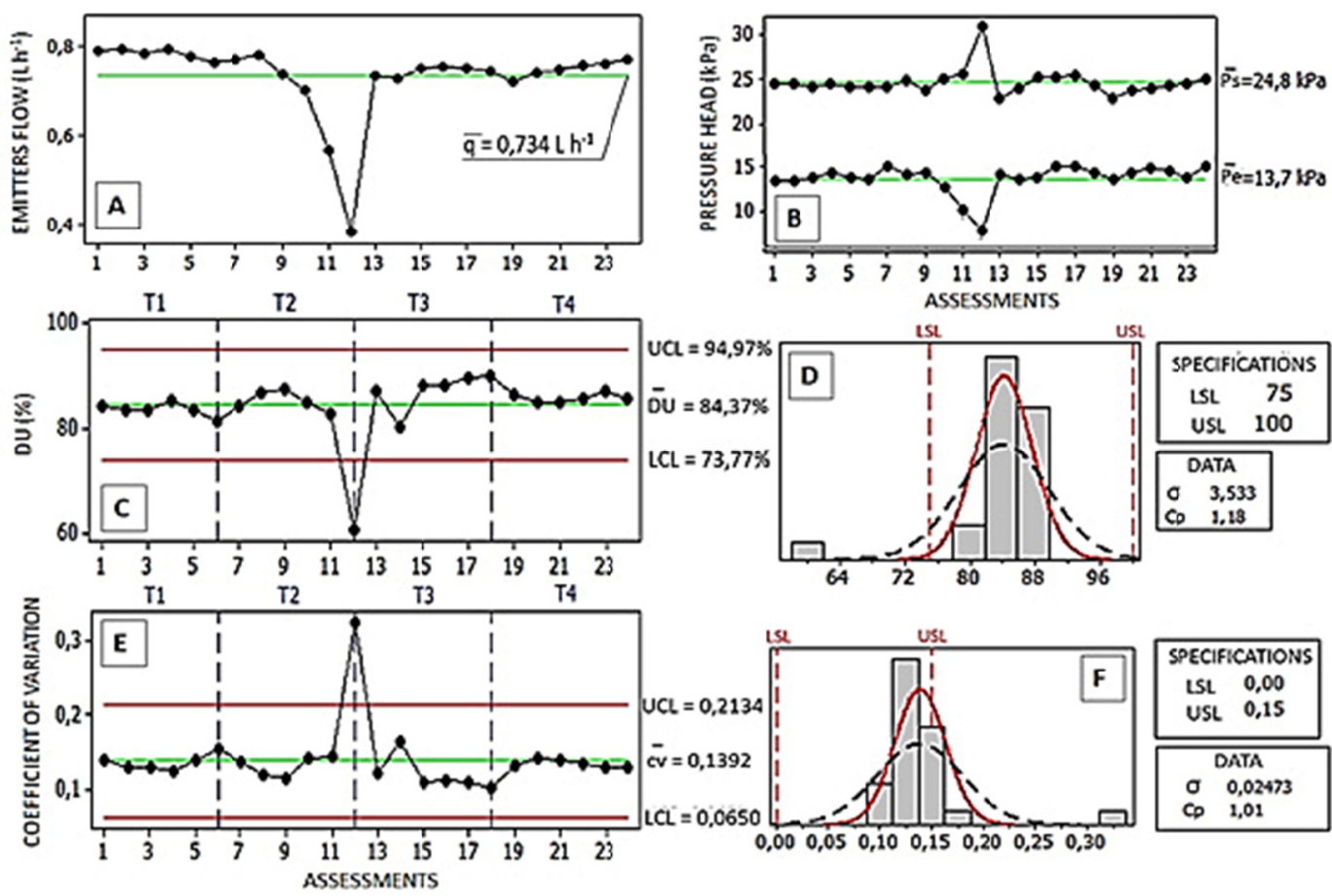

Figure 3. Charts referring to: A-Average emitters flow (q); B-Pressure head, pressure from start irrigation system $(\mathrm{Ps})$ and pressure from end irrigation system (Pe); C - Distribution Uniformity (DU); D — Capability process $(\mathrm{Cp})$ to $\mathrm{DU}$; E-Coefficient of variation (cv); F-Capability process $(\mathrm{Cp})$ to $\mathrm{cv}$

The clogging rate was also analyzed, being an initial reference source for the first assessment, and negative data (unclogging) were considered as $0 \%$. Figure 4 represents the clogging rate (CR) of the system throughout the assessments.

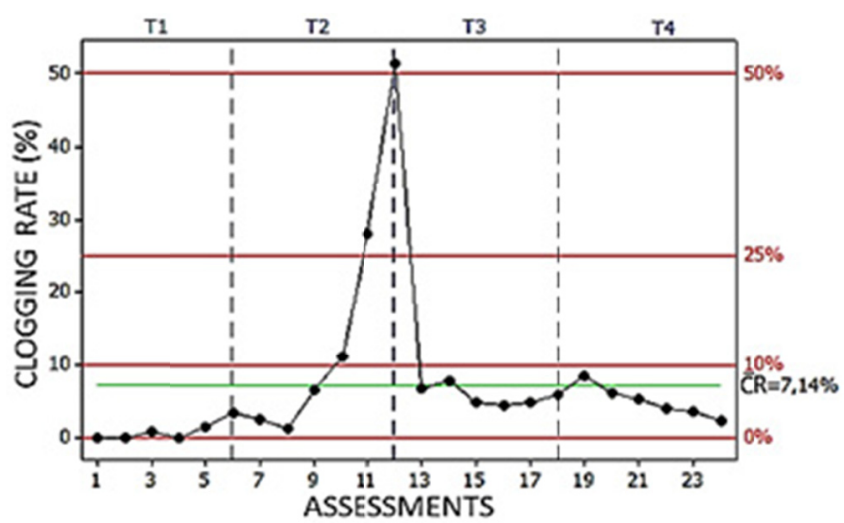

Figure 4. Clogging rate of the irrigation system

A more specific analysis was performed to identify the drippers that presented the highest sensitivity to the clogging, so that the means of CR between the treatments were compared, with $\mathrm{T} 1$ being the reference for the other treatments. Figure 5 shows the spatial distribution of the $\mathrm{CR}$ of the treatments for each evaluated dripper. 


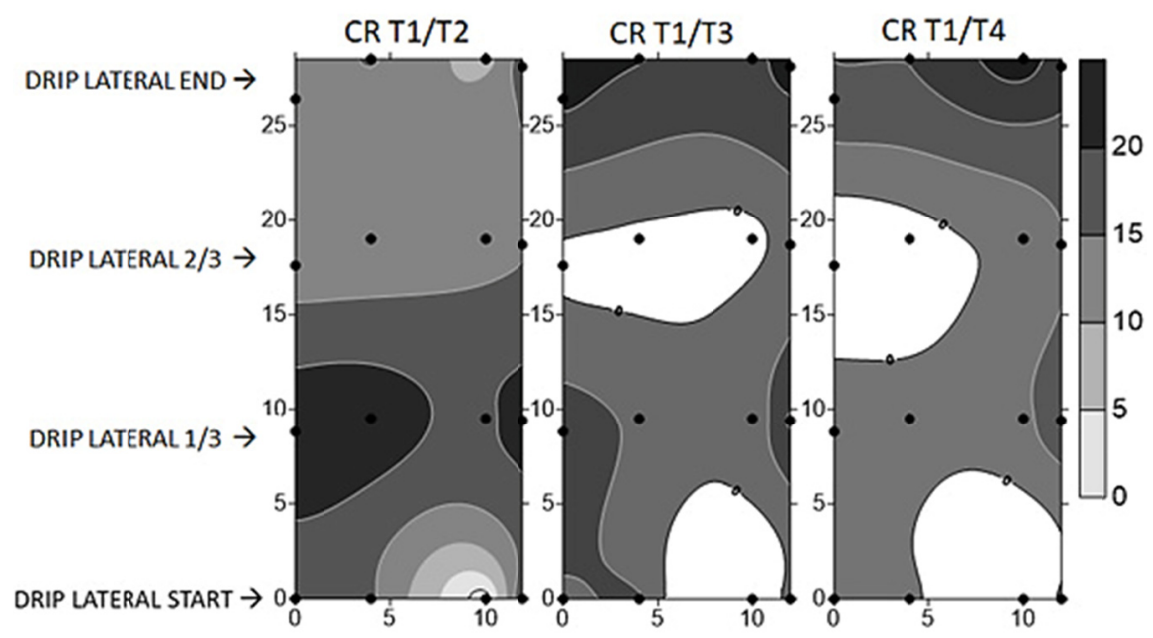

Figure 5. Spatial distribution of clogging rate for each evaluated dripper

\section{Discussion}

The Table 2 presents the irrigation water quality which the chemical elements that are more dangerous for clogging of drip emitters are iron, manganese and magnesium, however, the element that would be more problematic is the calcium, that react with other elements to form precipitates which could clog the emitters, but the calcium was not found in enough concentration for it to occur.

The time line of assessments follows the sequence of the treatments each six assessments (one by day), therefore, it is verified by Figure 3 that the assessment $12\left(6^{\text {th }}\right.$ fertigation day) was outside of the statistical control limits, that is, low DU and high cv, showing that there were problems from that point. The cause of this problem was the clogging by the application of the red $\mathrm{KCl}$ (assessments 7 to 12), which was not fully dissolved in the chemical tank because the fresh water was not enough and the line endings were not opened at the end of the assessments. The flow in this same point falls abruptly, while the initial pressure rises and the final pressure is reduced, thus verifying the clogging of the drippers.

This practice is made by the local farmers and was applied in this experiment for show the effects of this bad management, and Coelho et al. (2014) found lower performance and higher clogging rate of the emitters with application of red potassium chloride, same the results found in this experiment. If were applied water directly after $\mathrm{KCl}$ application, the result could be the same because the problem was the accumulate of not dissolved fertilizer in the irrigation tubes. But is verified that the DU is lower in the T4 (only water) than the T3 (chemigation), with low flow variation for the both treatments, showing that the $\mathrm{Ca}(\mathrm{ClO})_{2}$ presented effect of unclogging in the irrigation system.

It was observed that after the application of $\mathrm{Ca}(\mathrm{ClO})_{2}$ there was a uniformity stability, being close to the mean, which is also visualized by the flow that shows increase above average while the pressure remains stable and similar to T1, when the system presented no problems.

The average flow was lower than the emitter discharge because the system pressure was got by the water tank installation height, and it was not enough for the $2 \mathrm{~L} \mathrm{~h}^{-1}$, characterizing the most of irrigation systems of local farmers.

With the imposed conditions of specific limits for the process capability analysis $(\mathrm{Cp})$, the result for the DU and $\mathrm{cv}$ were acceptable, as both were above 1.0. Therefore, the process is capable of being executed and can further improve if the problem of clogging during application of the fertilizer is solved.

In the Figure 4, the $\mathrm{T} 1$ shows that the $\mathrm{CR}$ was below $10 \%$, suffering a considerable increase from the assessment 10 to 12 , where it reaches $50 \%$, reducing later to less than $10 \%$, during the unclogging phase and remaining thus until the end of assessments. According to Niu, Liu and Chen (2013), the degree of clogging has significance from $10 \%$, being severe at $25 \%$ and considered blocked at $50 \%$. Therefore, the reference lines in the chart can help to verify the moments in which the system already presents problems of clogging, verified from the assessment 10 . 
The chart also shows that the application of calcium hypochlorite was efficient to unclogging the system, returning to the initial characteristics of the process at the end of the assessments.

In the Figure 5 is verified that the clogging rate begins in the region of drip lateral $1 / 3$, following to the end of the drip lines, remaining in this region. Probably the undissolved sediments of the fertilizer were carried to the end of the lines as the assessments were passed, remaining at the ends of the drip lines. It can be said that the cleaning of the tubes with the opening of the end of the lateral lines would solve the problem, making the system more efficient and lasting for small farmers who use this irrigation system.

As reported by Deus, Ferraresi, Primo, Martins, and Testezlaf (2015), the KIFNET drippers with short period of use, have already presented clogging, but its uniformity is good and it is economically feasible for family farming, when the preventive maintenance is done for the longer irrigation system time of life.

Some recommendations can be mentioned to maintenance of the drip irrigation system, like: open the end lines after fertigation to release the fertilizer accumulation into the drip tubes; dissolve the fertilizer fully in fresh water before the application in the irrigation system; adequate the system design to the drippers flow be the recommended from manufacturer and ever verify the water quality and crop tolerance before the use of any chemical product in the irrigation system.

The use of calcium hypochlorite in the clearing of drippers clogged with red potassium chloride was efficient for the recovery of the localized irrigation system.

Statistical quality control charts were essential for the verification of the clogging problem in the drip irrigation system and for decision-making regarding the maintenance of the process, so that it remains acceptable.

The distribution maps of the clogging rate pointed out where the problem was centered, so that maintenance could be done at the affected site, reducing service time.

\section{References}

ANA (Nacional Water Agency). (2012). Conjuntura dos recursos hídricos no Brasil: Informe 2012 (p. 215). Ed. Especial, Brasília.

ANA (Nacional Water Agency). (2015). Conjuntura dos Recursos Hidricos no Brasil: Informe 2014. Brasília.

Aizenchtadt, E., Ingman, D., \& Friedler, E. (2008). Quality control of wastewater treatment: A new approach. European Journal of Operations Research, 189, 445-458. https://doi.org/10.1016/j.ejor.2007.06.001

ASABE (American Society of Agricultural and Biological Engineers). (2008). Design and installation of microirrigation systems (p. 6). St. Joseph.

ASABE (American Society of Agricultural and Biological Engineers). (1996). Field evaluation of micro irrigation systems (p. 792-7). St. Joseph.

Capra, A., \& Scicolone, B. (1998). Water quality and distribution uniformity in drip/trickle irrigation systems. Journal of Agricultural Engineering Research, 70, 355-365. https://doi.org/10.1006/jaer.1998.0287

Christofidis, D. (2006). Água: gênesis, gênero e sustentabilidade alimentar no Brasil. Brasília-DF.

Coelho, R. D., Ribeiro, P. A. D. A., Teixeira, M. B., Ribeiro, P. H. P., Ribeiro, N. L., \& Carvalho, J. J. D. (2014). Effect of the application of potassium chloride, soil particles and soluble iron in the discharge of drippers. Revista Brasileira de Agricultura Irrigada, 8, 210-219. https://doi.org/10.7127/rbai.v8n300209

Deus, F. P., Ferrarezi, R. S., Primo, R., Martins, G. A., \& Testezlaf, R. (2015). Susceptibilidade ao entupimento de um sistema de irrigação por gotejamento para agricultura familiar. Revista Coffee Science, 10(1), 102-112.

EMBRAPA (Brazilian Agricultural Research Corporation). (2011). Furticultura irrigada (p. 274). Brasília: Embrapa.

FAO (Food and Agriculture Organization). (2011). The state of the world's land and water resources for food and agriculture. Managing systems at risk. New York, USA.

Frigo, J. P., Vilas Boas, M. A., Frigo, J. P., \& Frigo, E. P. (2016). Comparação entre gráficos de controle de Shewhart, CUSUM e MMEP no processo de irrigação por aspersão convencional. Revista Irriga, 1(01), 56-70. https://doi.org/10.15809/irriga.2016v1n01p56-70

Frizzone, J. A., Freitas, P. S. L., Rezende, R., \& Faria, M. A. (2012). Microirrigação: Gotejamento e Microaspersão (p. 356). Maringá, PR: Eduem. 
Gonçalvez, P. U., \& Werner, L. (2009). Comparação dos índices de capacidade do processo para distribuições não-normais. Revista Gestão e Produção, 16(1), 121-132. https://doi.org/10.1590/S0104-530X200900010 0012

Henning, E., Walter, O., Souza, N. S, \& Samohyl, R. (2014). Um Estudo para a Aplicação de Gráficos de Controle Estatístico de Processo em Indicadores de Qualidade da Água Potável. Sistemas \& Gestão, 9, 2-13. https://doi.org/10.7177/sg.2014.v9.n1.a1

IBGE (Brazilian Institute of Geography and Statistics). (2009). Censo Agropecuário-Agricultura familiar 2006 (p. 265).

ISO 7870 (International Organization of Standardization). (2013). Shewhart control charts (p. 44).

Montgomery, D. C. (2013). Introduction to Statistical Quality Control (7th ed., p. 754). Arizona, USA.

Nakayama, F. S., \& Bucks, D. A. (1991). Water quality in drip/trickle irrigation: A review. Journal of Irrigation Science, 12(4), 187-192. https://doi.org/10.1007/BF00190522

Niu, W., Liu, L., \& Chen, X. (2013). Influence of fine particle size and concentration on the clogging of labyrinth emitters. Irrigation Science, 31(4), 545-555. https://doi.org/10.1007/s00271-012-0328-2

Pedrini, D. C., \& Ten Caten, C. S. (2011). Método para aplicação de gráficos de controle de regressão no monitoramento de processos. Revista Produção, 21(1), 106-117. https://doi.org/10.1590/S0103-6513201100 5000001

Tolentino Júnior, J. B., Marinho, L. B., Souza, C. F., \& Frizzone, J. A. (2014). Desenvolvimento de um modelo numérico para modelagem do bulbo molhado em irrigação por gotejamento. Revista Irriga, 1, 11-20. https://doi.org/10.15809/irriga.2014v1n1p11

\section{Copyrights}

Copyright for this article is retained by the author(s), with first publication rights granted to the journal.

This is an open-access article distributed under the terms and conditions of the Creative Commons Attribution license (http://creativecommons.org/licenses/by/4.0/). 